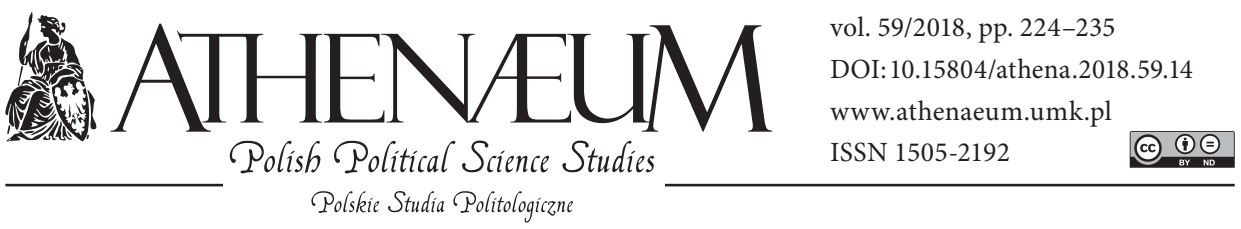

\title{
THE STOCK MARKET CHANNEL IN THE MONETARY POLICY TRANSMISSION PROCESS
}

\author{
KANAŁ GIEŁDOWY W PROCESIE TRANSMISJI IMPULSÓW \\ POLITYKI PIENIĘŻNEJ
}

Magdalena Redo*

\begin{abstract}
The growing number of empirical studies proves the existence of the negative relations between short-term interest rates and the stock prices. It points to permeability of the stock market channel in the monetary policy transmission process; it also proves the strength of the central bank instrument which makes it possible to react to disadvantageous turn of events on financial markets (by providing liquidity, easier access to credit or restoring investors' trust), or to excessive enthusiasm of investors. This confirms the importance of monetary policy in economic policy and is an argument for more frequent use of monetary tools rather than fiscal tools to affect economy. It mainly corresponds to countries with high and/or growing - decade after decade public debt, as well as with strong impact of the public finance sector on GDP which limits possibilities and development perspective of respective economies as well as lowers flexibility of fiscal policy and its feature of supporting economic
\end{abstract}

\begin{abstract}
ABSTRAKT
Coraz liczniejsze badania empiryczne dowodzą istnienia negatywnego związku między krótkoterminowym oprocentowaniem a poziomem cen akcji. Wskazuje to na drożność kanału giełdowego w procesie transmisji polityki pieniężnej i dowodzi siły instrumentarium banku centralnego, przy którego pomocy ma on możliwość reagowania na niekorzystny rozwój wydarzeń na rynkach finansowych (przez dostarczanie płynności, ułatwienia w dostępie do kredytu czy przywrócenie zaufania inwestorów) albo na nadmierny entuzjazm inwestorów. Potwierdza to tym samym wagę polityki pieniężnej w polityce gospodarczej i stanowi argument na rzecz silniejszego wykorzystania pieniężnych narzędzi oddziaływania na gospodarkę kosztem fiskalnych. Dotyczy to zwłaszcza państw o wysokich i/lub rosnących z dekady na dekadę długach publicznych oraz silnej ingerencji sektora finansów publicznych w PKB, ograniczających możliwości i perspektywy rozwojowe ich gospodarek oraz obniżających elastyczność
\end{abstract}

* Nicolaus Copernicus University in Toruń, Faculty of Political Sciences and International Studies. ORCID: https://orcid.org/0000-0002-1274-3181. 
processes that is needed not only in the context of shocks. It would be advised to return to actions that were observed before the financial crisis of 2008 in terms of integrating capital markets in Europe and to intensify them - not only due to obvious advantages of improved effectiveness and attractiveness of the European financial market, but also due to expected strengthening of the stock market channel in the monetary transmission policy process as well as the increased effect of monetary policy on economic processes and their effectiveness.

Keywords: monetary policy, central bank, the transmission mechanism of monetary policy, channels of monetary transmission, stock market channel, Q Tobin effect polityki fiskalnej i jej zdolność do wspierania procesów gospodarczych, potrzebną nie tylko w sytuacjach szoków. Należałoby więc powrócić do obserwowanych przed kryzysem finansowym z 2008 r. działań w kierunku integracji rynków kapitałowych w Europie i zintensyfikować je - nie tylko z uwagi na oczywiste korzyści w postaci poprawy efektywności i atrakcyjności europejskiego rynku finansowego, ale także z uwagi na oczekiwane dzięki temu wzmocnienie działania i znaczenia kanału giełdowego w procesie transmisji polityki pieniężnej, a tym samym wzrost siły oddziaływania polityki pieniężnej na przebieg procesów gospodarczych i poprawę skuteczności jej działania.

Słowa kluczowe: polityka pieniężna, bank centralny, mechanizm transmisji polityki pieniężnej, kanały transmisji polityki pieniężnej, kanał giełdowy, efekt Q Tobina

\section{INTRODUCTION}

The main aim of this paper is to analyze empirical studies of econometric modeling to verify hypotheses on negative correlation between short-term interest rates and the stock prices which would point to permeability of the stock market channel in the process of monetary transmission policy and also to the effect of monetary tools of the central bank on real economic units. By using the method of inductive reasoning, a synthesis of results from the comparative analysis was made; those results, along with the results confirming permeability of different channels of transmitting monetary policy, point to the ability of central bank to shape the course of economic processes, which is regarded as an argument against excessively expansive fiscal policy which contributes to accumulation of exceeding public debt in contrast with established credibility and dependence on external financing. This analysis is of both cognitive and decisive character. 


\section{THE STOCK MARKET CHANNEL}

The basis to formulate and understand the mechanism of stock market channel ${ }^{1}$ in transmission of monetary policy is found in works of Tobin from 1969 and 1977. The Tobin's Q theory places stock prices as central in the process of influencing investment through monetary policy (see more in Redo, 2016). Changes of interest rates in the central bank influence prices of financial and non-financial assets, thus they directly influence inflation. Reduction of interest rates lowers the profitability of investments based on interest rates; thus, the interest in stocks or real estate increases and so does their price. Moreover, cheaper loans boost consumption and expansion of enterprises and their future profits, which is an additional incentive for subsequent growth of stock prices. In addition, changes in interest rates influence the discount rate used to estimate present value of future profits from assets (stocks, real estate, etc.), causing current change in their price (lower short-term interest rates mean lower discount rate for future cash flows, thus the increase of current asset value). Moreover, Bernanke \& Kuttner (2004) indicated that monetary policy also influences expectations in terms of future changes in stock prices (and also profits from investing in stocks) as well as expectations towards the level of future dividends. It is explained with the influence of monetary policy on the risk premium (through the influence on the cost of borrowed capital and the situation in enterprises' balances) and on the tendency of investors to take risk (through the influence on consumption level - Campbell \& Cochrane, 1999, or the relations with the change of inflation level - Brandt \&Wang, 2003). As an alternative explanation, Bernanke \& Kuttner (2004) pointed to sensitivity of stock prices to impulses of monetary policy, suggesting the same direction of further research on the correlation between monetary policy and expected changes in stock prices. Ioannidis \& Kontonikas (2006) had similar conclusions but also pointed out that monetary policy not only influences current stock prices but also expectations of the increase in their prices in the future (higher interest rates lower expectations of increased stock prices).

It is worth nothing that the stock market plays the central role in the model used by FED to analyze the transmission of monetary policy impulses into economy. In Europe, especially Continental Europe, where stock markets are still

1 This is the key channel for transmitting monetary policy both from the point of monetarists and Keynesians (Mishkin, 1995). 
scattered, the importance of this transmission channel differs greatly depending on the value of capital market and its development degree. In the upcoming years, there will most likely be a shift from the tendency for stock market mergers observed before the crisis of 2008 where the main driver was found in market powers seeking to improve the effectiveness of capital markets. This should strengthen the effectiveness and importance of the stock market channel in the process of transmitting monetary policy not only in Europe. Thus, this channel should be monitored at all times, as along with integration of financial markets and dynamically multiplied hundreds of trillions of dollars in hands of private investors, it will most likely play one of the central, if not the dominant role in transmitting monetary policy because it accurately reflects the market's opinion on monetary policy and its effects.

The strength of the stock market channel in the process of transmitting monetary policy is confirmed by the growing number of empirical research in this area, which confirm negative correlation between short-term interest rates and the stock prices. This correlation, on the basis of American economy, was indicated by, i.a., Rigobon \& Sack (2002); Kuttner (2000); Thorbecke (1997), or Bernanke \& Kuttner (2004). Chami, Cosimano, \& Fullenkamp (1999), on the other hand, not only confirmed in their research the importance of the stock market channel in transmission of monetary policy impulses into economy, but also confirmed the increase of its importance along with development of stock markets and the increase of their economic importance. Ioannidis \& Kontonikas (2006) confirmed this correlation in 10 out of 13 analyzed OECD countries where tightening of monetary policy was accompanied with the stock prices decrease on national capital markets (which was an effect of the discount rate increase and the decrease of present value of future cash flows) ${ }^{2}$. However, it must be noted that, as Bernanke \& Kuttner (2004) point out, even though monetary policy of FED strongly influences American stock markets, it is responsible for the change of stock prices in small part.

2 The research included 10 Western European economies (the United Kingdom, Germany, France, Switzerland, Italy, Netherlands, Belgium, Sweden, Finland, Spain) and the US, Canada, and Japan within the period of January 1972-July 2002. Only in Finland, Japan and Spain stock markets seem to have no relation with the level of short-term interest rates. 


\section{EXPECTED AND NOT EXPECTED ACTIONS WITHIN MONETARY POLICY}

When analyzing the influence of monetary policy on economy, there must be a distinction between the instances where the market accurately foresaw actions of central bank and the instances that are called surprises in terms of the strength of reaction of monetary policy or the direction of interest rate change. As Ehrmann \& Fratzscher (2004) indicate, many analyses lack in terms of establishing the relations between the monetary policy and stock markets, as the change of interest rates level as a whole is regarded as the reason for the change in stock prices. As indicated by Kuttner (2000), on the day of the decision, markets react only to unexpected components of central bank interest rate changes (the difference between the interest rate anticipated by markets and the actual change). The expected change was included in the stock prices in previous days. As Gürkaynak, Sack, \& Swanson (2005) indicate, the unexpected decision of monetary policy is determined by 2 factors: the level in which market participants were able to accurately predict the decision (target surprise) and the level in which the decision is different from the established path of monetary policy (path surprise). Also Craine \& Martin (2003) indicated that stock markets react strongly to unexpected impulses of monetary policy - two times stronger than for example debt market, while at the same time pointing out that the stock markets and the stock market channel, which is usually omitted in books and analyses, is, due to the value of stock markets, an important channel of transmitting monetary policy in a short period. The above are confirmed in the results of the Bomfim (2000) research which indicated that since the changes in Federal Open Market Committee (FOMC) decision announcement were introduced in February 1994, the decision comes into force on the day of its announcement and not on the next day as it was previously; moreover, FOMC started to pay more attention to have the interest rate changes implemented on regular meetings and not outside of them as it used to happen previously. The volatility of stock prices decreased in the days prior to the decision on interest rate level and increased in the days after the decision. Bomfim (2000) indicated also that the volatility of stock prices is greater when interest rates are increased more than the market expects than when they are decreased more than the market expects them to be. These results were confirmed by Lobo (2000), who showed that the reaction of stock markets is stronger in tightening of monetary policy than in a situation of loosening of monetary policy and that volatility of stock prices is decreased within the 
period before the expected change of both most important FED interest rates (the federal funds rate and discount rate) as a result of significant increase of risk aversion than when the market expects the change only in one of them. In following research, Lobo (2002) confirmed strong positive reaction of stock markets to increased relaxation of monetary policy than the market expected, whereas in the case of stronger increase of interest rates by FED it only indicated the increase of stock prices fluctuations, that expired the next day (this increase in fluctuations appears only in the data from the period of 1994-2001, whereas the entire study included the period between 1981 and 2001). Chen (2007), on the other hand, indicated certain asymmetry in reaction of the stock markets towards monetary policy: stronger in periods of bear market, weaker in bull market. The above conclusion is completed by the results of Kurov's research (2010), who indicated that the FED's monetary policy in bear market has stronger influence over the stocks that are more sensitive to market liquidity changes, credit terms and investors' sentiment.

The above research was conducted on the basis of daily statistics from stock markets. However, to have a much more detailed view on the reaction of stock markets on decisions of central banks, it is necessary to use data of higher frequency (for example, every few minutes) which was indicated in a significantly lower number of empirical research. By conducting research in that way, Lunde \& Zebedee (2009) indicated a specifically increased stock prices volatility at the time of the decision's announcement on interest rates level (where the increased volatility is sustained until the end of a given day). Moreover, Farka (2009) indicated a strong and, more importantly, stronger than indicated in previous research, influence of FED's monetary policy on stock prices and their volatility ${ }^{3}$ at the time of the decision's announcement (stronger in the case of expansive monetary policy which is in contrast with the results of Bomfim (2010) or Lobo (2000) obtained from data of significantly lower frequency). Similarly, Hussain (2011) pointed out to strong, short-term reactivity on both continents (the USA and the majority of European stock markets) to unexpected decisions made by central banks. However, he noticed that the level of interest rates is connected to the economic situation and it is unknown in what respect the change of stock

3 This volatility is abnormally low hours before the decision is made, radically increases when the decision is being announced and then decreases in the hours after the decision is made but is on higher level until the end of the day and disappears on the next day. This volatility scheme is confirmed by Lobo $(2000,2002)$ and Bomfim $(2000)$ in their research. 
prices is a reaction only to the change of interest rates and to what extent it is a reaction to other economic variables; thus, Hussain (2011) indicated that empirical research based on data of high frequency is key to separating the influence of monetary policy. He indicated also that, in the case of stock markets in the euro zone, the press conference that takes place 45 minutes after the ECB's decision is crucial; thus, this proves that it includes certain additional information important to stock markets. Similarly to the above, research of Andersson (2007) pointed out strong volatility not only on the stock markets, but also on bond markets at the time of the decision of central banks on the level of interest rates in both the USA (stronger) and in the euro zone. Although Andersson (2007) indicated that financial markets in the euro zone react strongly to path surprises, conclusions of Hussain (2011) were completely different. Ehrmann \& Fratzscher (2004) confirmed the relations stated by Andersson (2007) on the USA market. However, Wongswan (2009) indicated that the majority of stock markets (out of those 16 analyzed countries) react to changes in the base interest rate in the USA. The similar conclusions can be found in the research of Conover, Jensen, \& Johnson (1999) conducted with the use of data with much lower frequency. They indicated that in some countries (out of 16 analyzed countries), stock markets react not only to interest rate changes of their central banks, but also to interest rate changes in FED. The significant role of monetary policy in economy is confirmed by the strong (yet short-term) reaction of the market to central bank's decisions. It confirms the power of instruments of the central bank with which it can react to disadvantageous course of events on financial markets (by providing liquidity, easier access to credit or restoring investors' trust) or to excessive enthusiasm expressed by investors.

\section{DETERMINANTS OF DIFFERENT SENSITIVITY OF STOCK PRICES TO THE IMPULSES OF MONETARY POLICY}

It is obvious that the stock prices do not always react in the same way to the impulses of monetary policy. Taking into consideration the effectiveness of monetary policy and permeability of the stock market channel, identifying reasons of different shares reaction is crucial. On the basis of data derived from the New York stock exchange market between 1953 and 1990, Thorbecke (1997) indicated that the stock prices of smaller businesses react stronger to impulses of monetary policy; this suggests the relationship with financial constraints. Maio 
\& Tavares (2007) indicated that the low-priced stocks (of lower capitalization companies) and stocks of underestimated value (the so-called value stocks, with lower $P / E$ - price-earnings and $P / B V$ - price-to-book value indicators) react more strongly to the impulses of FED's monetary policy. Ehrmann \& Fratzscher (2004) indicated that the reaction of stock prices to tightened monetary policy of FED is strongly dependent on industry and the financial situation of a business. They also indicated that small businesses with lower credit rating, lower debt, lower cash-flows and high price earnings ratio (P/E) and high Tobin's $\mathrm{Q}$ ratio are much more sensitive to changes in FED interest rates. This sensitivity is also greater in the case of unexpected changes of interest rates, as well as in the case of changes in monetary policy direction and in the periods of high market volatility. Industries such as technology, communication or consumer goods react much more strongly (even 2, 3 times stronger). However, Bernanke \& Kuttner (2004) indicated that high technologies and telecommunication are the most sensitive towards unexpected decisions in monetary policy, whereas the reaction of energetic and utilities is far less significant. Ehrmann \& Fratzscher (2004) point out that, despite the improvement in understanding the reaction of stock markets to the impulses of monetary policy, there is still need for advanced research that will explain these dependencies in greater detail and will also explain the differences in reaction of stock prices of particular businesses on monetary impulses. Bernanke \& Kuttner (2004) suggest that these differences do not come from the influence of monetary policy on real interest rates but rather from the influence on the expected future additional profits, thus on the expected level of future dividend.

Empirical research on permeability of the stock market channel in Europe indicates its strong activity and significant homogeneous functioning in the euro zone countries. Angeloni \& Ehrmann (2003) indicated strong and negative effect of unexpected tightening of monetary policy after 1999 in both selected countries (in 10 out of 11 euro zone countries - except for Ireland) and also in data which treats the euro zone as a whole (EuroStoxx). Their research shows that telecommunications, consumer goods, technology and finance are the most sensitive. On the basis of data for the euro zone between 1980 and 1998, Peersman \& Smets (2001) indicated strong influence of the stock market channel, suggesting that stock markets in the euro zone immediately react to tightened monetary policy with significant decrease (whereas the real estate prices significantly slower).

It must be noted that the market value of stocks greatly influences actual decision-making of businesses. Thus monetary policy which, through the stock 
market channel influences the prices on equity markets, also influences the decisions regarding investment, mergers, acquisition, entering stock market, issue and purchase of treasury bonds, change in capital structure through the Tobin's $\mathrm{Q}^{4}$ effect; thus it influences key decisions in terms of financial management of a given business. Overestimation of a business's market value (company's market capitalization) makes them issue new stocks and/or bonds as well as realization of investments coming from cheaply acquired capital. Thus, it is a factor stimulating the development of businesses and the entire economy. It must be noted that the overestimation of equity market not only reduces financial constraints and might lead to economic development and employment stimulation, it also leads to ineffective capital allocation, not optimal decision-making (illusion of information), overinvestment, increased speculation and significant dips, thus to worse economic efficiency (Chirinko \& Schaller, 2011b). It also generates agency $\operatorname{cost}^{5}$ and destroys the core value of the company (Jensen, 2004). That is why central banks should analyze the access of particular businesses to external financing and take into consideration the influence of monetary policy on the condition of financial markets which transfers directly on the market cost of capital and free access to finance; this conditions company's development, economic growth and employment rate and, at the same time, may be a great source of financial imbalances (Redo, 2016). It might be argued that in this case monetary policy should support financial stability in its broader sense (leaning against the wind - see more in Redo, 2018).

\section{CONCLUSIONS}

Subsequent development of financial markets along with fiscal expansion of not only major economies and quantitative loosening of major central banks strengthen permeability of the stock market channel (and Q Tobin's channel) as well as risks that are involved in the process. It must be noted that it does not concern only economies with developed capital markets, it also concerns less developed markets, thus more sensitive to capital flows (Chirinko \& Schaller,

4 The Tobin's Q effect reflects influence of market valuation on financial decisions of given business, including investment. It is strictly connected to the exchange channel.

5 A classic conflict of interests between shareholders and managers who, at the time of market overestimation, think about expansion and not about maximization of the company's value; this generates costs referred to by Jensen \& Meckling (1976) as agency costs. 
2011a). Their relatively low developed capital markets are specifically receptive to overestimation due to small size of the market in comparison to the capital flowing into developing economies. Thus, it is essential in those countries to monitor the situation on both national capital market and on capital markets of neighboring countries, as well as it is important to monitor the permeability of the stock market channel (and Q Tobin's channel). Too extended, expansive monetary policy might lead to relatively fast overestimation of the stock market and, as a result, to overinvestment and ineffective allocation of capital or destruction of a business' value; this can lead to speculative bubbles which can be generated by the increase in capital of businesses, banks and households as well as by improvement in their liquidity in the face of current risk-taking tendencies and very low interest rates (Redo, 2016).

It must be noted that monetary policy not only influences current stock prices (causing the change of discount rate used to estimate present value of future profits from assets), but also expectations regarding the change in their prices (causing the change of expectation in terms of future increase of prices). It can be concluded that stock markets react far more strongly to unexpected impulses of monetary policy, not only in the context of own central bank. This leads to an assumption that the Polish stock market is also influenced by the ECB's monetary policy. It must be stressed that reactiveness of a stock market varies depending on the direction of the central bank's actions, economic situation or tendencies on stock markets (level of their prices). Aside from that, stock prices of given businesses do not react in the same way to impulses of monetary policy; thus, it is important, with respect to efficiency of a stock market channel and therefore monetary policy effectiveness, to conduct further research in terms of identifying reasons for such a strong asymmetry of stock prices of given businesses in response to monetary policy impulses. Monetary policy which, through the stock market channel, influences the stock prices, also influences key decisions in terms of financing through the Q Tobin's channel. Thus, monetary policy of the central bank should take into consideration current situation and specific features of a given stock market as well as its access to external financing when making a decision; monetary policy should support financial stability in its broader sense. 


\section{REFERENCES:}

Andersson, M. (2007). Using Intraday Data to Gauge Financial Market Responses to FED and ECB Monetary Policy Decisions. European Central Bank Working Paper, 726.

Angeloni, I., \& Ehrmann, M. (2003). Monetary Policy Transmission in the Euro Area: Any Changes After EMU? European Central Bank Working Paper, 240.

Bernanke, B.S., \& Kuttner, K.N. (2004). What Explains the Stock Market's Reaction to Federal Reserve Policy? NBER Working Paper, 10402.

Boivin, J., Kiley, M.T., \& Mishkin, F.S. (2010). How Has the Monetary Transmission Mechanism Evolved Over Time? NBER Working Paper, 15879.

Bomfim, A.N. (2000). Pre-Announcement Effects, News Effects, and Volatility: Monetary Policy and the Stock Market. Monetary and Financial Market Analysis, October 25.

Brandt, M.W., \& Wang, K.Q. (2003). Time-Varying Risk Aversion and Unexpected Inflation. Journal of Monetary Economics, 50(7), 1457-1498.

Campbell, J.Y., \& Cochrane, J.H. (1999). By Force of Habit: A Consumption-Based Explanation of Aggregate Stock Market Behavior. The Journal of Political Economy, 107(2), 205-251. DOI: 10.1086/250059.

Chami, R., Cosimano, T.F., \& Fullenkamp, C. (1999). The Stock Market Channel of Monetary Policy. IMF Working Papers, 22.

Chen, S.S. (2007). Does Monetary Policy Have Asymmetric Effects on Stock Returns? Journal of Money, Credit and Banking, 39(2-3), 667-688.

Chirinko, R.C., \& Schaller, H. (2011a). Fundamentals, Misvaluation, and Business Investment. Journal of Money, Credit and Banking, 43(7), 1423-1442. DOI: 10.1111/j.1538-4616.2011.00430.x.

Chirinko, R.S., \& Schaller, H. (2011b). Do Bubbles Lead to Overinvestment?: A Revealed Preference Approach. CESifo Working Paper, 3491.

Conover, C.M., Jensen, G.R., \& Johnson, R.R. (1999). Monetary Environments and International Stock Returns. Journal of Banking and Finance, 23(9), 1357-1381. DOI: 10.1016/S0378-4266(99)00007-2.

Craine, R., \& Martin, V. (2003). Monetary Policy Shocks and Security Market Responses. Berkeley Economics Working Paper.

Ehrmann, M., \& Fratzscher, M. (2004). Taking Stock: Monetary Policy Transmission to Equity Markets. European Central Bank Working Paper, 354.

Farka, M. (2009). The Effect of Monetary Policy Shocks on Stock Prices Accounting for Endogeneity and Omitted Variable Biases. Review of Financial Economics, 18(1), 47-55. DOI: 10.1016/j.rfe.2008.05.003.

Gürkaynak, R., Sack, B., \& Swanson, E. (2005). Do Actions Speak Louder Than Words? The Response of Asset Prices to Monetary Policy Actions and Statements. International Journal of Central Banking, 1(1), 55-93.

Hussain, S.M. (2011). Simultaneous Monetary Policy Announcements and International Stock Markets Response: An Intraday Analysis. Journal of Banking and Finance, 35(3), 752-764. DOI: 10.1016/j.jbankfin.2010.09.002. 
Ioannidis, C., \& Kontonikas, A. (2006). Monetary Policy and the Stock Market: Some International Evidence. Retrieved from: https://www.researchgate.net/publication/5080997_Monetary_Policy_and_the_Stock_Market_Some_International_evidence.

Jensen, M.C. (2004). Agency Cost of Overvalued Equity: European Corporate Governance Institute. ECGI - Finance Working Paper, 39.

Jensen, M.C., \& Meckling, W.H. (1976). Theory of the Firm: Managerial Behavior, Agency Cost, and Ownership Structure. Journal of Financial Economics, 3(4), 305-360. DOI: 10.1016/0304-405X(76)90026-X.

Kurov, A. (2010). Investor Sentiment and the Stock Market's Reaction to Monetary Policy. Journal of Banking and Finance, 34(1), 139-149. DOI: 10.1016/j.jbankfin.2009.07.010.

Kuttner, K.N. (2000). Monetary Policy Surprises and Interest Rates: Evidence from the Fed Funds Futures Markets. Federal Reserve Bank of New York, Staff Reports, 99.

Lobo, B.J. (2000). Asymmetric Effects of Interest Rate Changes on Stock Prices. The Financial Review, 35(3), 125-144. DOI: 10.1111/j.1540-6288.2000.tb01424.x.

Lobo, B.J. (2002). Interest Rate Surprises and Stock Prices. Financial Review, 37(1), 73-91. DOI: 10.1111/1540-6288.00005.

Lunde, A., \& Zebedee, A. (2009). Intraday Volatility Responses to Monetary Policy Events. Financial Markets and Portfolio Management, 23(4), 383-399. DOI: 10.1007/ s11408-009-0114-1.

Maio, P., \& Tavares, J. (2007). Monetary Policy and the Cross-Section of Equity Returns: Small versus Large and Value versus Growth. Bilkent University Faculty of Business Administration.

Mishkin, F. (1995). Symposium on the Monetary Transmission Mechanism. Journal of Economic Perspectives, 9(4), 3-10.

Peersman, G., \& Smets, F. (2001). The Monetary Transmission Mechanism in the Euro Area: More Evidence from VAR Analysis. European Central Bank Working Paper, 91.

Redo, M. (2016). Znaczenie efektu Q Tobina dla skuteczności polityki pieniężnej. Finanse, 1.

Redo, M. (2018). Should Central Banks Lean Against the Wind? (forthcoming).

Rigobon, R., \& Sack, B.P. (2002). The Impact of Monetary Policy on Asset Prices. NBER Working Paper, 8794.

Thorbecke, W. (1997). On Stock Market Returns and Monetary Policy. The Journal of Finance, 52(2), 635-654. DOI: 10.2307/2329493.

Tobin, J. (1969). A General Equilibrium Approach to Monetary Theory. Journal of Money, Credit, and Banking, 1(1), 15-29. DOI: 10.2307/1991374.

Tobin, J. (1977). Monetary Policies and the Economy: The Transmission Mechanism. Cowles Foundation Discussion Papers, 456.

Wongswan, J. (2009). The Response of Global Equity Indexes to US Monetary Policy Announcements. Journal of International Money and Finance, 28(2), 344-365. 